\title{
ECONOMIC REVITALISATION THROUGH AGRICULTURE: ROLE OF AGRICULTURAL CREDIT GUARRANTEE SCHEME FUND IN NIGERIA
}

\author{
Tiamiyu S.A. ${ }^{1 *}$, Bwala M.A. ${ }^{2}$, Alawode V.O. ${ }^{1}$ \\ ${ }^{1}$ National Cereals Research Institute, Bida, Nigeria \\ ${ }^{2}$ Department of Agricultural Economics, IBB University, Lapai, Nigeria \\ ${ }^{*}$ E-mail: satiamiyu2@gmail.com
}

\begin{abstract}
The study provides information on how best to explore and exploit the potential of Agricultural Credit Guarantee Scheme Fund in revitalizing the Nigeria economy that is currently under recession. The relationship among Agricultural Credit Guarantee Scheme Fund, Commercial Banks loan supplied to agriculture and Agriculture share of Gross Domestic Product was determined using secondary data obtained from the website of the Central Bank of Nigeria. Annual values of Agricultural Credit Guarantee Scheme Fund, Commercial Banks loans to Agriculture and Agricultural share of Gross Domestic Products for a period of thirty three years (1981-2013) were collected and analyzed using Correlation Matrix and Ordinary Least Square regression. Results showed that no negative relationship exists among the three variables. There was positive and statistically significant relationship between Agricultural Credit Guarantee Scheme Fund and Commercial Bank Loan to agriculture. The Credit Guarantee Scheme Fund also impacted positively and significantly on agriculture share of Gross Domestic Product during the period. It was concluded that the Agricultural Credit Guarantee Scheme Fund is a suitable policy strategy to stimulate agricultural production in order to achieve sustainable growth of Gross Domestic Product in Nigeria. Awareness campaign on how to tap the benefit of the Agricultural Credit Guarantee Scheme Fund should be intensified to cover large proportion of rural agricultural producers. Agricultural programmes and policies which aimed at increasing productivity of agriculture should be evaluated and efficacious ones should continue.
\end{abstract}

\section{KEY WORDS}

Gross domestic product, economic diversification, agriculture, bank loan supply, credit guarantee scheme, Nigeria.

Nigeria economy has been under technical recession since third quarter of 2015 as a result of declining price of petroleum oil globally. Diversification of Nigeria revenue source from petroleum-based to other sectors was identified by policy makers as a way forward in transforming the economy from recession to prosperity. In this regard, agriculture was given top priority among the alternative non-oil sectors considered for improvement in recognition of the role play by agriculture as the mainstay of Nigeria economy before the exploration of petroleum. In the 1960s, agricultural commodities such as cocoa, cotton, groundnut, palm oil and rubber accounted for 70\% of Nigerian's exports (Lawal, 1997, Ogunkola et al., 2008). The advent of petroleum exploration in the 1970s shifted the main export-based revenue of the nation from agriculture to petroleum. Since 1980s petroleum sector has consistently dominated the Nigeria federally generated revenue (Table 1). The consequence of overdependence on petroleum revenue was the technical recession, which has been traced to declining growth of Nigeria Gross Domestic Product (GDP) arising from global fall in prices of crude oil since 2015. As the country is pre-occupied with the challenges of economic recession, there is need to evaluate past agricultural policies and programmes with a view to providing information on how best to explore and exploit the potential of agriculture in revitalizing the agriculture share of Gross Domestic Product which has remained stagnated below $40 \%$ in the last three decades (Table 2).

Nigeria agricultural sector is dominated by small scale, resource-poor farmers who are characterized by low capital base, low adoption of modern technologies and low production 
(Daramola, 2004). According to Mejeha and Obunadike (1998), access to formal credit is an important factor for adoption of technologies. The low marketable surpluses arising from low production make it hard to earn enough income to take advantage of improved technologies which is important factor in raising agricultural productivity. This situation justifies the need for provision of credit to Nigeria farmers. According to Obeta, (1992) and Ammani, (2012), farmers in Nigeria have limited access to credit from the formal institutions due to cumbersome loan procedures and high interest rates. The bulk of credit needs in rural areas are met by informal lending agencies such as commodity traders and moneylenders sometimes at higher interest rates (Nwaru, 2004). Support to agricultural sector is often geared towards large farms by formal credit institution (CBN, 2005). In a bid to addressing the credit problem of small scale agricultural producers and processors, the Agricultural Credit Guarantee Funds Scheme was established by Decree No. 20 of 1977, and started operations in April, 1978 with share capital and paid-up capital of N100 million and N85.6 million respectively (CBN, 2005). The Agricultural Credit Guarantee Scheme Fund was designed to encourage commercial banks to increase lending to the agricultural sector by providing guarantees against risk in agricultural lending up to $75 \%$ of the amount in default net of any security realized. The capital base of the scheme was increased to N3 billion in March 2001. As at $31^{\text {st }}$ December 2004, the credit scheme has a total investment of N4.4 billion (CBN, 2005).

Table 1 - Summary of Federal Government Revenue (N' billion)

\begin{tabular}{|l|l|l|l|}
\hline \multicolumn{1}{|c|}{ Period } & \multicolumn{1}{|c|}{ Oil revenue } & \multicolumn{1}{c|}{ Non-oil revenue } & \multicolumn{1}{c|}{ \% share of oil sector } \\
\hline $1981-1990$ & 200.81 & 78.27 & 72 \\
\hline $1991-2000$ & 4359.59 & 1211.89 & 78 \\
\hline $2001-2010$ & 37999.00 & 10094.43 & 79 \\
\hline $2011-2013$ & 23714.17 & 7817.22 & 75 \\
\hline
\end{tabular}

Source: Computed from Central Bank of Nigeria, 2014 Statistical Bulletin, Table B.1.1.

Table 2: Gross Domestic Product of Nigeria (N' billion)

\begin{tabular}{|l|l|l|l|}
\hline \multicolumn{1}{|c|}{ Period } & \multicolumn{1}{|c|}{ Total GDP } & \multicolumn{1}{|c|}{ Agric. share of GDP } & \multicolumn{1}{c|}{ \% share of Agric sector } \\
\hline $1981-1990$ & 1858.15 & 566.9 & 31 \\
\hline $1991-2000$ & 30421.53 & 10009.2 & 33 \\
\hline $2001-2010$ & 172893.66 & 57321.8 & 33 \\
\hline $2011-2013$ & 120350.73 & 39716.4 & 33 \\
\hline
\end{tabular}

Source: Computed from Central Bank of Nigeria, 2014 Statistical Bulletin, Table C.1.1.

What has been the impact of the Credit Guarantee Scheme Fund to the agricultural sector? This study is an attempt to provide answer to the question by investigating the extent to which the Agricultural Credit Guarantee Scheme Fund influenced Commercial Bank loans to agriculture and the agriculture share of Gross Domestic Product.

Many researchers have carried out studies related to financial intervention on agriculture and agricultural output (Anyanwu, et al 2010, Igwe and Esonwume, 2011, Udoh, 2011, Armas, et al, 2012, Olajide, et al 2012, Adofu, et al, 2012, Ammani, 2012, Zakaree, 2014). Most of these studies focused on government spending as the only explanatory variable for agricultural output while a few considered Credit Guarantee Scheme Fund as explanatory variable with focus on food production (Zakaree, 2014). This present study proposes to address the gap by considering Credit Fund as explanatory variable for Commercial Bank Loan to Agriculture and the Gross Domestic Product using Ordinary Least Square regression model. Although some studies have used Ordinary Least Square regression in the past (Igwe and Esonwume, 2011, Adofu, et al 2012, Ammani, 2012 and Olajide, et al 2012), none of them treated effect of the Agricultural Credit Guarantee scheme Fund on agriculture share of Gross Domestic Product. The specific objectives of this study are: to determine the relationship between Agricultural Credit Guarantee Scheme Fund (Credit Fund), Commercial Bank Loan to Agriculture (Agric. Loan) and agriculture share of 
Gross Domestic Product (Agric.GDP); to determine the effect of Credit Fund on Agric. Loan; and, to determine the effect of Credit Fund on Agric. GDP.

\section{METHODOLOGY OF RESEARCH}

Nigeria is located within the Equator and the Tropic of Cancer on the main latitude and longitude $10^{\circ}$ North and $8^{\circ}$ East respectively. The latitude of Nigeria falls within the tropical zone but the climatic conditions are not entirely tropical in nature. The climatic condition varies in most parts of the country, in the north the climatic condition is arid and to the south there is an equatorial type of climate. The country has a land area of about $923,768 \mathrm{~km}^{2}$ with a wide range of vegetations that are suitable for various kinds of agricultural production.

Secondary data covering a period of thirty three years, 1981 to 2013 was used for the study. The time series data on values of Agricultural Credit Guarantee Scheme Fund, Commercial banks Loans to agriculture and agricultural share of GDP were collected from the Statistical Bulletins of the Central Bank of Nigeria (CBN, 2015). The relationship between Credit Fund, Agric. Loan and agric. GDP were analyzed using correlation matrix and ordinary least square regression. The strength of correlations is measured by the values of its coefficients. A value less than 0.45 implies weak, 0.45 to 0.55 implies moderate, 0.56 to 0.65 implies fairly strong, 0.65 to 0.75 implies strong while value greater than 0.75 implies very strong relationship. Positive sign indicate direct relationship while negative sign indicates inverse relationship.

In regression analysis, the annual value of agric. GDP and annual value of agric. Loan were separately made deterministic function of the annual value of Credit Fund. The following functional forms were estimated using ordinary least square regression:

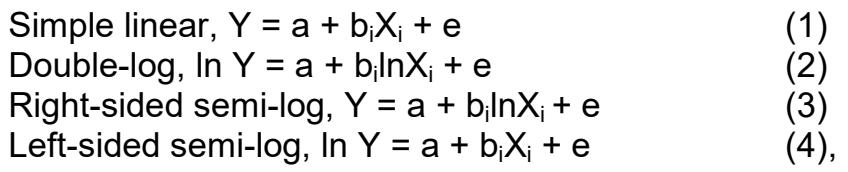

Where: $\mathrm{Y}=$ Dependent variables (Agric.GDP, or Agric. Loan), $\mathrm{X}_{\mathrm{i}}=$ Credit Fund, $\mathrm{a}=$ constant term, $b_{i}=$ regression coefficients and $e=$ random error term.

The parameters generated from the estimated equations were used as basic criteria for chosen lead equations that were used to determine effect of Credit Fund on Agric. Loan or on Agric. GDP; on the assumption that other explanatory variables remain constant (Ammani, 2012).

\section{RESULTS AND DISCUSSION}

Correlation Estimates of relationship among Credit Fund, Agricultural Loan and GDP. The relationship that exist among the Agricultural Credit Guarantee Scheme Fund (Credit Fund), Commercial Loan to Agriculture (Agric. Loan), Agriculture share of Gross Domestic Product (Agric. GDP) and overall Gross Domestic Product (Total GDP) is presented in Table 3 . The values of correlation coefficients indicate a strong positive relationship among all the variables. The positive signs imply that an increase in any of the variables will lead to increase in any other variables. Agric. GDP and overall GDP were strongly correlated. This implies that any effect of Credit Fund on Agric.GDP can be used to explain impact of Credit fund on overall GDP which has direct bearing on the economic recession. Recession implies a consistent declining of overall GDP for a period of three quarters.

Regression Estimates of relationship between Credit Fund and Agricultural Loan. The statistical parameters generated from the estimated regression equations that expressed the relationship between Agric. Loan and Credit Fund are presented in Table 4. Based on the values of Multiple R, R-square and F-statistics, double-log equation best fit the relationship, and thus selected as lead equation. F-statistics is statistically significant implying that a significant proportion of changes in Agric. Loan supplied to agriculture were as a result of 
changes in Credit Fund. The sign of the coefficients were positive in conformity with apriori expectation since Credit Fund is expected to encourage commercial banks to make loans available to agricultural sector. The coefficient of Credit Fund was statistically significant at $1 \%$ level. The coefficient value of 0.8431 implies that 100 percent increase in Credit scheme fund lead to 84 percent increase in the Agric. Loan. This result showed that Credit Fund can be used to stimulate availability of credit for agricultural production. However, commercial banks did not utilize fully the potential of the Credit Fund during the period as indicated by the less percentage increase in loans supplied to agriculture by commercial banks compared with the percentage increase in the Credit Fund during the period.

Table 3 - Correlation Analysis of Credit Fund, Agric. Loan and GDP

\begin{tabular}{|l|l|l|l|l|}
\hline \multicolumn{1}{|c|}{ Variables } & \multicolumn{1}{|c|}{ Credit Fund } & \multicolumn{1}{c|}{ Agric. Loan } & \multicolumn{1}{c|}{ Agric. GDP } & Total GDP \\
\hline Credit Fund & 1 & & & \\
\hline Agric. Loan & 0.840458 & 1 & & \\
\hline Agric. GDP & 0.930476 & 0.947698 & 1 & \\
\hline Total GDP & 0.928108 & 0.945238 & 0.997141 & 1 \\
\hline
\end{tabular}

Source: Computed by Author from CBN 2015.

Table 4 - Statistical parameters from regression estimate of commercial bank loan and ACGSF

\begin{tabular}{|l|l|l|l|l|l|l|}
\hline \multicolumn{1}{|c|}{ Model } & \multicolumn{1}{c|}{ Coefficient } & \multicolumn{1}{c|}{ t-stat } & \multicolumn{1}{c|}{ R } & R-square & Adjusted R & \multicolumn{1}{c|}{ F value } \\
\hline Linear & $2.08 \mathrm{E}-05$ & 8.6988 & 0.8423 & 0.7094 & 0.7000 & 75.6701 \\
\hline Left-sided Semi-log & $1.66 \mathrm{E}-07$ & 5.7127 & 0.7161 & 0.5128 & 0.4971 & 32.6354 \\
\hline Right-sided semi-log & 78.4553 & 7.1638 & 0.7895 & 0.6234 & 0.6234 & 51.3201 \\
\hline${ }^{*}$ Double-log & 0.8431 & 11.8097 & 0.9045 & 0.8181 & 0.8123 & 139.4688 \\
\hline
\end{tabular}

Source: Computed by Author from CBN 2015. *Lead equation.

Table 5 - Statistical parameters from regression estimate of Agriculture GDP and ACGSF

\begin{tabular}{|l|l|l|l|l|l|l|}
\hline \multicolumn{1}{|c|}{ Model } & \multicolumn{1}{c|}{ Coefficient } & \multicolumn{1}{c|}{ t-stat } & \multicolumn{1}{c|}{ R } & R-square & Adjusted R & \multicolumn{1}{c|}{ F value } \\
\hline Linear & 46.9122 & 17.7373 & 0.9541 & 0.9103 & 0.9074 & 314.611 \\
\hline Left-sided Semi-log & 0.007865 & 5.8269 & 0.7230 & 0.5227 & 0.5073 & 33.953 \\
\hline Right-sided semi-log & 4234.159 & 7.6306 & 0.8078 & 0.6526 & 0.6414 & 58.2273 \\
\hline${ }^{*}$ Double-log & 1.1490 & 40.9831 & 0.9909 & 0.9819 & 0.9813 & 1679.18 \\
\hline
\end{tabular}

Source: Computed by Author from CBN 2015. *Lead equation.

Regression Estimates of relationship between Credit Fund and Agricultural GDP. The statistical parameters generated from the estimated regression equations that expressed the relationship between Agric. GDP and Credit Fund are presented in Table 5. Double-log equation best fit the relationship, and thus selected as lead equation. F-statistics is statistically significant implying that a significant proportion of change in Agric. GDP was due to change in Credit Fund. The sign of the coefficients were positive in conformity with apriori expectation since access to credit is expected to empower farmers to procure the right inputs at the right time for agricultural production. Generally the coefficient of credit fund was statistically significant at $1 \%$ level. The coefficient value of 1.1490 implies that 100 percent increase in credit scheme fund lead to 115 percent increase in Agric. GDP. The higher proportionate increase in Agric. GDP for every unit increase in Credit Fund implies that Credit Fund has multiplier effects on the growth of agriculture share of GDP. This implies that Credit Fund is an appropriate strategy to stimulate agricultural production for economic revitalization. The result is expected because some innovations such as the self-help linkage programme launched under the Agricultural Credit Guarantee Scheme encouraged farmers to form themselves into groups (CBN, 2015). Group formation enable farmers save part of their savings as security to access credit from the bank, as well as inculcating the culture of savings and banking habit in group members leading to building up of resources for financing their farm projects without recourse to bank in the long run. These reason couples with easy avenues for farmers to participate in some other agricultural programmes that require group 
formation in the course of their operation enhance productivity growth leading to multiplier effect on GDP growth during the period.

\section{CONCLUSION}

The study determined the effect of Agricultural Credit Guarantee Scheme Fund on commercial bank loan to agriculture and agriculture share of GDP during the period (19812013). It was established that Agricultural Credit Guarantee Scheme Fund impacted positively on commercial bank loan to agriculture and agriculture share of GDP. The implication is that the Credit Scheme Fund has influenced bank loan supplied to agricultural sector with consequential multiplier effects on Agricultural share of GDP during the period. The finding showed that Credit Scheme is a suitable policy strategy to stimulate rural agricultural financing for sustainable Agric. GDP growth. Since there was strong positive correlation between Agric. GDP and the overall GDP, agricultural financing through the Credit Guarantee Fund has potential to transform Nigeria economy from its present recession to prosperity if enabling environments are provided to access the Credit Scheme Fund for agricultural production.

The following recommendations are made based on the findings:

The capital base of the Credit Fund should be strengthened to enable commercial banks cover large proportion of agricultural producers.

Awareness campaign on how to tap the benefit of the Credit Fund should be intensified to reach out as many rural farmers as possible.

Provision of credit should be supported with necessary infrastructural services needed to make the credit facility work. These include: release of productivity-enhancing technologies developed by various agricultural research institutes; effective dissemination of improved technologies to farmers by the extension agents; provision of support services like transport facilities and markets; and

Government agricultural policies and programmes which aimed at revamping agriculture in the last three decades should be evaluated with the aim of retaining those that have complimentary relationship with the Credit Fund.

Group formation should continue to be encouraged among agricultural producers in order to enable them benefit from the Credit Fund.

Unemployed youths should be mobilized to take advantage of the scheme and engage in agricultural business.

\section{REFERENCES}

1. Adofu, I., Abula, M. and J.E. Agama (2012). The effects of government budgetary allocation to agricultural output in Nigeria. Sky Journal of Agricultural Research, 1(1):1-5.

2. Ammani, A.A. (2012). An investigation into the relationship between agricultural production and formal credit supply in Nigeria. International Journal of Agriculture and Forestry, 2(1): 46-52

3. Anyanwu, S.O., Ibekwe, U.C. and O.M. Adesope (2010) Agricultural share of the Gross Domestic Product and its implications for rural development, Report and Opinion, 2(8):26-31

4. Armas E.B., Osorio C.G., Blanca M.D. (2012). Agriculture Public Spending and Growth: The Example of Indonesia, Economic Premise, 2:9

5. CBN (2005). The Agricultural Credit Guarantee Scheme Fund (ACGSF): Guidelines and Operation. Development Finance Department, Central Bank of Nigeria

6. Central Bank Nigeria (2015). Statistical Bulletin for the 2014, retrieved on 22 November, 2015

7. Daramola, A.G. (2004).Competitiveness of Nigeria Agriculture in a global economy: Any Dividends of Democracy? Inaugural lecture Series 36, Federal University of Technology, Akure, $36 \mathrm{p}$. 
8. Igwe K, Esonwume C. (2011). Determinants of agricultural output: Implication on Government Funding of Agricultural Sector in Abia State, Nigeria. Journal of Economics and Sustainable Development 2(4):86-91.

9. Lawal, A. A. (1997). "The Economy and the State from the Pre-Colonia Times to the Present" In Osuntokun, A. and Olukoju, A. (Eds) Nigerian Peoples and Cultures. Ibadan: Davidson

10. Mejeha RO, Obunadike A (1998). "The Impact of Credits on Adopting Innovations on Fertilizer Use, Yam Minisett and Cassava in Anambra State of Nigeria" Nigeria Journal of Agriculture Teacher Education, 1: 40-44

11. Nwaru J.C. 2004. Rural Credit Markets and Arable crop Production in Imo State of Nigeria. PhD Thesis Michael Okpara University of Agriculture, Umudike, Nigeria

12. Obeta, M.E. (1992). Agricultural Credit in Nigeria: Performance at Farm Level. African Review of Money Finance and Banking 2:173-184

13. Ogunko E.O., Bankole A.S., Adewuyi A. (2008). China-Nigeria Economic Relations, Report Submitted to African Economic Research Consortium (AERC), February, 2008] www.aercafrica.org/documents/

14. Olajide,O.T., Akinlabi B.H. and A.A. Tijani (2012). Agriculture Resource and Economic Growth in Nigeria. European Scientific Journal. 2012;8(22):103-155.

15. Udoh E. (2011) An examination of public expenditure, private investment and agricultural sector growth in Nigeria: Bounds Testing Approach. International Journal of Business and Social Sciences 2(13):285-292.

16. Zakaree, S.S. (2014). Impact of Agricultural Credit Guarantee Scheme Fund on Domestic Food production in Nigeria. British Journal of Economics, Management and Trade $4(8): 1273-1284$ 